\title{
Otherness in Interior Identity: A Reflection about the Freudian Concepts of Unconscious, Superego, and Id
}

\author{
Jacqueline de Oliveira Moreira \\ Pontifícia Universidade Católica de Minas Gerais (Brazil)
}

Theoretical, psychoanalytical constructs referring to the unconscious, the superego, and id, enjoy an autonomy within the I. As such, this study contemplates the discussion of these foreign entities that inhabit the interior of the I, producing an effect of foreignness. In the first section, I will develop a reflection on the state of foreignness of the unconscious. I will begin with an analogy used by Freud, which addresses the thesis of universality of consciousness with the psychoanalytical thesis of the subconscience within the I. Affirmation of consciousness in the other may be used analogously for affirm the idea of another inhabiting our own being. I shall continue, seeking to understand how the process of unconscious repression produces the effect of foreignness. The idea of a moral censor present in the entity of the superego constitutes the theme of the second section. The superego follows the principle of otherness in its constitution and in its effects on the I. Finally, a reflection on the dimension of otherness in the Id seems urgent to me, as with this concept, Freud radicalized in the idea of the foreign as the origin of the subject.

Keywords: psychoanalysis, otherness, unconscious, super-ego and id

\begin{abstract}
Los constructos teóricos psicoanalíticos que se refieren al inconsciente, al superyó y al ello disfrutan de autonomía dentro del yo. Como tales, este estudio contempla la discusión de estas entidades foráneas que habitan el interior del yo, produciendo un efecto de algo ajeno. Primero, desarrollaré una reflexión sobre el estado foráneo del inconsciente. Empezaé con una analogía empleada por Freud, que aborda la tesis de la universalidad de la conciencia con la tesis psicoanalítica del inconsciente dentro del yo. La afirmación de la conciencia en el otro puede usarse de forma análoga para afirmar la idea de que otro habite nuestro propio ser. Continuaré la búsqueda para entender cómo el proceso de la represión inconsciente produce el efecto de lo ajeno. La idea de un censor moral presente en la entidad del superyó constituye el tema de la segunda parte. El superyó sigue un principio de otredad tanto en su constitución como en sus efectos sobre el yo. Finalmente, una reflexión sobre la dimensión de la otredad en el Ello me parece urgente, ya que con este concepto Freud radicalizó la idea de lo foráneo como el origen del sujeto. Palabras clave: psicoanálisis, otredad, inconsciente, superyó, ello
\end{abstract}

Correspondence concerning this article should be addressed to Jacqueline de Oliveira Moreira, Rua Congonhas,161, São Pedro, Belo Horizonte, Minas Gerais, Brazil - CEP 30.330-100. Phone: (31) 3223-3951. E-mail: jackdrawin@yahoo.com.br

How to cite the author of this article: Moreira, J.O. 
Freudian psychoanalysis, frequently, is presented as a theory and practice that broke with the tradition psychology and medicine of the 19th century. But, despite all of the discrepancy and rupture of psychoanalysis with traditional means of confronting psychiatric problems, we can find within history a series of theoretical presuppositions that constitues a fertile ground from which Freudian psychoanalysis bloomed. Garcia-Roza endeavours to succinctly explain the"preconditions for the emergence of psychoanalysis". "From the archaeological perspective it (psychoanalysis) may be seen as the effect of a series of connections between knowledge and practice that constitute an historical basis that enables its emergence"(Garcia Roza, 1987, p. 23).

Garcia-Roza's work seems quite relevant to us, in so much as would be that of the influence of the tripod Illustration, Romanticism and Scientificism in Freudian psychoanalysis. Yet, it is more common to point to Freud's divergence from the the thinking of his era. Freud was audacious enough to dedicate himself to aspects that were not commonly valued. Dreams, phallic imagery, and symptoms without physiological causes were an area of great interest to Freud. Freud was very reticent to abandon physiological prepositions, the medical materialism of this time. But, we can say that in the text of The Interpretation of Dreams, Freud's attempt to break with the materialist tradition appears more clearly.

But, perhaps Freud's greatest rupture with his era has been the creation of the concept of the unconscious, considered a system that possesses an operational mode distinct from the conscious. Freud is even more audacious upon revealing that the true psychic reality is found in the unconscious.

Modern thought is defined by the primacy of the I, unequivocally affirmed in Cartesian rationalism. The starting point for philosophical reflection is the first certainty reached, and that of the I as the primary existence (Cogito) and conceived as subject, that is, as an existence completely distinct from others. All of modern thought has come to be interpreted as included in the paradigm of the philosophy of the subject and the conscious, in which the image of the solitary soul rules, thinking about its own experiences, so that, from them, it may interact with others and the world. There are many problems with this concept, however: How could the I, in its isolation, thinking as a monad, be able to know the objectivity of the world and relate with the other? This difficulty was perceived by the very modern philosopher, Spinoza, who refuted the Cartesian starting point, and, by Kant, who established the irreducible acknowledgement of the other as a requirement for practical reasoning, as we can see in the second formula of the categorical imperative presented in "The Foundation of Customs." "Act in such manner as to consider humanity, whether in yourself, or in any other, also, too, as the end, and not only the simple means" 1 . However, even acknowledging these limits of conscientialist philosophy, this remains. So, the philosophical tradition begun by Descartes is interested in the guarantee and unity of knowledge and truth, since the subject is the principle rhetorician of modern knowledge. The problem of otherness does not represent a possibility of responding to modern epistemological problems. The Cartesian method of questioning is an instrument for arriving at certainty. The Cartesian conclusions are clear and distinct: I can question everything, but I can not think that the I, which thinks all thoughts and questions all things, doesn't exist at the same time that it thinks. The real existence of my I, as subject which thinks, is absolutely certain. Thus, "Cogito ergo sum" is a certainty, an irrefutable truth, Archimedian principle of knowledge. The thinker is the only survivor of the universal destruction produced by doubt, the firm foundation on which modern epistemology is solidly constructed.

However, psychoanalysis operates a subversion in the subject inaugurated by Descartes, despite Lacan's ${ }^{2}$ insistence that the difference between Freudian psychoanalysis and humanist practices is precisely in the possibility of the first to produce its concepts from the scientific radicality of the Cartesian subject. The Lacanian reading of the Cartesian cogito is established in paradoxical hermeneutics, as in Descartes, the subject is conscious, rational and autonomous, while that the conception of Freudian subjectivity points to the irreducibility of the unconscious, revealing the unconscious constitutes the true psychic reality. According to Lacan (1966), the famous Cartesian proposal - I think, therefore I am - announces the presence of a thought prior to "self-awareness." Descartes would be affirming a pure thought, unequipped with the qualities of consciousness, and, thus, similar to what Freud called "unconscious thought."3 The Lacanian interpretation of Descartes is reversed, since it doesn't begin with the "order of reasons", and from the internal logic of the Cartesian discourse, but aims to demonstrate that psychoanalysis is part of the great traditions of modern science initiated by Galileo and Descartes. ${ }^{4}$

1 Severino, E.. Modern philosophy. Lisboa, Editions 70. Spinoza's refusal from the Cartesian perspective is clearly expressed in the statement: "The scholastics begin with things; Descartes begins with thought; I, myself, begin with God." See, Verneaux, R. (1963). Histoire de la philosophie moderne (History of modern philosophy). Paris Beauchesne.

2 See. Lacan, J. (1998). Science and truth. In Writings (p. 870). Rio de Janeiro: Jorge Zahar.

3 See, Milner, J-C. (1996). The clear work Lacan, Science, Philosophy (p. 33-34).Rio de Janeiro, Jorge Zahar.

4 See, Milner, J-C. (1996). The clear work Lacan, Science, Philosophy (p. 36/38).Rio de Janeiro, Jorge Zahar. 
Despite Lacan's proposal, we can confirm that Freud dealt a blow to modern narcissism, dethroning the consciousness from its palace. The subject is not this rational, indestructible unit. Psychoanalysis revealed a contradiction in this subject and injected the problem of otherness into the breast of identity. The idea of "otherness" appears to be associated spontaneously with "exteriority", and the "other" and that which is outside of the "I", in the same manner that the "object" is classically opposite to the "subject." Psychoanalysis showed us, however, that, if the "other" is identified as foreign, this foreignness is not that of another in relation to an integrated and autocentric I, but, is that which lives this same I and makes it foreign to itself. The unconscious, which, from the theory of repression, is the fundamental discovery of Psychoanalysis, represents this otherness that not only exists in us, and, from which we can not escape, but is also that which constitutes our identity in such a way that we can not say "I" without acknowledging an opaque side which resists control of the announced that intends to apprehend it completely and exhaust it. When Freud, contrary to his own medical education, really began to listen to the hysteria and proposed "free association", beginning a form of thinking and a communicational act which went beyond the limits of the conscious intention of the I, it was as though he opened a silence, allowing an "other", like a whisper, to blow in our own ear, that of the analyst and of the patient, the words that should be freely said. Thus, to listen to the other that lives within us, we must quiet the "I" that wants to imposes itself as controller of the consciousness, which is assumed in the belief of an "I" equal to "myself," refusing to be open to the challenge of the difference. However, refusal of this acknowledgement is destined for failure, with the certainty of this inevitable presence of otherness that runs us over in our daily life, that steals a memory and imposes an unexpected one, that hides from us the meaning of our own actions and tosses us into foolishness, into incongruence and astonishment with our own words and actions.

We can, thus, conclude that the "problem of otherness" covers the entire development of psychoanalytic theory, or, more specifically, all of the development of Freudian thought. However, if Freud doesn't use the term, and doesn't elevate it to the statute of a concept, if he doesn't articulate it theoretically in his metapsychology, it is because he calls it in many other ways, many different ways. Thus, to use an expression of Lacan's, one of his surprising neologisms, we can say that the "otherness" is an "extimity" in the Freudian discourse, it is the most exterior and intimate, intimate exteriority. What shouldn't surprise us, since we know that the unconscious is exactly this "familiar stranger" (Das Unheimliche [German: the Uncanny or Bizarre]), "this" from which comes the "I", the most exterior and the most intimate, foreign land to which we are viscerally connected as to a "Fatherland". Therefore, Milner (1996) is able to state that the theme of the other is "so intimate, that even Freud, himself, doesn't perceive it; so intimate, that this intimacy is extimity. It is beyond internal." 5

However, our effort, what we would like to do in this work, would be to define, in the other forms of the Freudian designation - the Unconscious, Id and Superego - the presence and the relevance of the problem of otherness as constituent of the subject. But, primarily, we thought of taking the field of the conscious I, sustenance of the modern dream of autonomy, as a reference around which we can circumscribe a discussion about the otherly dimension of the unconscious, the superego and the Id. For sovereign I, the unconscious system, the psychic instances of superego and the Id are presented as true aberrations, as strange foreigners. Freud (1917) revealed that the modern individual, or the sovereign I, considers the mental as identical to the conscient (Freud, 1917, p. 177). Thus, the radicality of the Freudian proposal will be in unveiling a reality behind the announced I, thus, a rupture in the identity, a strange principle that is not necessarily opposed to the $\mathrm{I}$, but that may have a disconnected aspect in relation to the images of the sovereignty of the I. If, on one side, the unconscious system, the superego or the Id are perceived by the I as foreigners, on the other hand, the Freudian theory, through these concepts, confirms the dimension of otherness as constitutive of the individual. In this context, we indent to specify the point in which the I may base itself to defend this thesis of foreignness of the unconscious system, the superego, and the Id, in relation to the ideal of the sovereignty of identity. Thus, the modern dream presents an I as pure identity, an individual thought of as sovereign, and Freudian theory puts forth a new concept of the individual, which included the I and the identity, but adding the otherness. We would like to explain the possible argument for this "I" which sustains the thesis of strangeness of the unconscious system, of the superego and the Id.

\section{The Unconscious as Other}

The article "The Unconscious" (Freud, 1915c), which is the third metapsychological text, defines and announces the essential characteristics of the purpose of psychoanalysis. The first attempt at theoretical formulation of the concept of the unconscious appears in chapter VII of the Interpretation of Dreams. Fifteen years prior, Freud, who had become a worldwide celebrity and had already begun the international

\footnotetext{
5 Cited by, Fernandes, L. R. (2000). O olhar do engano - autismo e outro primordial (The look of deception - autism and the primordial other). São Paulo, Escuta.
} 
psychoanalytical movement, already had vast clinical experience and a respectable theoretical drive, and was, thus, perfectly prepared to take up the construction of his metapsychological synthesis as a type of ultimate foundation of his theory. However, an attempt should be made to deepen and clarify the central concept of psychoanalysis: the unconscious.

In this article, the concept of the unconscious is approached from three dimensions which constitute a metapsychology, being specifically, the topical, dynamic and economical aspects. Discussion about the topographical record revolve around the distinction between the descriptive unconscious or preconscious, and the unconscious system which refers to repressed content, and which has its own characteristics. Attempts to elucidate the interaction and communication between the systems is a central theme in the approach to the psychic process in its dynamic aspect. The economical perspective is treated, overall, when Freud dedicates himself to the task of comprehension of the process of repression and from the vicissitudes of free energy that circulates in the representational chain.

Freud begins the discussion defending the necessity and legitimacy of introducing the idea of a unconscious system as a means to consistently apprehend psychic processes that are clinically manifested. The thesis is based on the criticism of conscientialism and points to the limit of the intentional conscience. Parapraxes ("Freudian slips"), phallic acts, reveal a dimension which goes beyond the powers of intentional consciousness, thus, they are apparently a psychic product expressed in language and actions lacking conscious intention and will, and that, thus, escape, as in a brief flash, the effort of the I to maintain its behavior under its own control. In this way, dreams, phallic acts and neurotic symptoms, all a group of phenomena that would come later to be called "formations of the unconscious", would remain unintelligible if we insisted in equating them and reducing the totality of the psychism of the conscience, since we would not be able, without contradiction, to infer something like a conscious intention subjacent to these phenomena and that would remain, nonetheless, imperceptible to the conscious mind. Consequently, Freud can assert that the equivalence between conscious and psychism would result in a vicious circle typical of petitio principii.
This, Freud's statement, constitutes the principal banner of psychoanalysis in the critique against conscientialism of psychology and philosophy which would supposedly be dominant in the 19th Century. In this struggle, Freudism has the romantic movement as an ally in its critique of the illustrated primacy of reason. Thus, the romantic philosophy of Schelling and Schopenhauer, as much as the romantic literature of Goethe and Tieck, worked with the idea of a blind force that would antecede and prevail over the presumption of intentional consciousness and its presence of autonomy. In Schopenhauer ${ }^{6}$, for example, we don't find direct mention of the term "unconscious", but the philosophy thereof conferred a positive status to the non-cognizant, and, in this manner, created the conditions that made the study of the elements that went beyond the limits of reason possible.

Freud, ever being considered an "Aufklärer (scout)", and "Illustrated", was, in a certain way, plunged deeply in the mysterious waters of the Romantic tradition ${ }^{7}$ and also ended up converting to a critic of reason and the powers of the conscious mind. Freudism points out and dedicates itself to explaining gaps in the consciousness. The phenomena to which psychoanalysis glances are fundamentally distinct from conscious phenomena. Of course, we still can't neglect to mention that Freud intended to produce a science of the unconscious, which, hence, implies the existence of belief in reason, which has never been repudiated. One could say that the over-determination Freud suffered in the creation of psychoanalysis produced in the author a kind of "skeptical belief" in reason. But our goal is not to reflect here on Freudian thinking's epistemological ambiguities, but only to emphasize that psychoanalysis constructed its object in polemic juxtaposition to the conscientialist project. It is in the depths of the philosophy of conscious, and exactly in opposition to this paradigm that Freud would delineate his research objective.

Perhaps this rigid opposition between the unconscious and the idea of intentionality should be refined. Since, in Chapter VII of The Interpretation of Dreams, we find indications of the idea of a unconscious intentionality, an idea that would be present in the notion of metarepresentation. Affirmation of an unconscious determinism, of a psychic causality, would betoken this idea of a kind of

\footnotetext{
6 Regarding Schopenhauer's contributions to Freud see: Assoun, P.L., (1978). Freud, filosofia e filósofos (Freud, Philosophy and Philosophers). Rio de Janeiro: Francisco Alves; Moreira de Oliveira, J. (1998). Freud e a filosofia: a herança schopenhaueriana (Freud and philosophy: the Schopenhauerian heresy) Psicanálise e Universidade (Psychoanalysis and Universality) (Revista da Pós-Graduação em Psicologia Clínica / Post-graduate Clinical Psychology Journal - PUC / SP), São Paulo, number 8, 1998.

7 See Andrade, Ricardo S., (2001) regarding the relationship between Freud and romanticism. A face noturna do pensamento freudiano - Freud e o Romantismo alemão (The nocturnal face of Freudian thought - Freud and German romanticism). Niterói: Eduff. The author presents ample discussion on the Freud's relationship with romanticism, considering aesthetics, medicine and romantic philosophy. Also see Loureiro, I. R. B. (2000). O carvalho e o pinheiro - Freud e o estilo romântico (The oak and the pine - Freud and romantic style). Doctorate Thesis (PUC/S.P.). São Paulo.
} 
unconscious intentionality. We can say that there is a subversion in the notion of intentionality, because unconscious intention can only be known a posteriori

Nonetheless, the concept of the unconscious appears to be contrary to the identity of the consciousness. Would the principle of otherness, then, be unconscious? In the search for the answer to this question, we intend to reflect on the dimensions of otherness present in the metapsychological article "The Unconscious" (Freud, 1915c) from two approaches: first, the other becomes present in the Freudian text as a rhetorical resource for argumentation, through the principle of the analogy; then, we will explain the enigmas of otherness within the process of production of the contents of the unconscious.

Freud, upon defending the proposal of the existence of the unconscious as legitimate, revealed that the postulation of this idea is not removed in the usual way of thinking or producing concepts. That which makes one aware is, evidently, the conscious/pre-conscious system, since it is in this system that we find the faculties of perception, judgement, reflection and rationality, which compose the process of awareness/knowledge. The unconscious, itself, can only be conceived and accessed in the light of conscious processes. One little exception: this statement does no negate the thesis that the unconscious system possess another operational logic distinct from the logic of the conscious/preconscious system. Freud intends to demonstrate that this thesis that proposes the universality of consciousness, a presupposition of any theoretical production, can also be valid for the establishment of the unconscious through the principle of analogy. Thus, if the unconscious is not immediately accessible, it is also not the consciousness of the other, which is only accessible to use through inference. That is, if we must infer the consciousness of the other person, interpreting the signals of their presence from immediate experience in our own consciousness, in the same manner, we can infer the unconscious, via the various indications of its presence, the formations of the unconscious mind, as if it were a type of "other" within us. Thus, the unconscious can be called the "otherly-other".

Freud uses the argument of analogy to refute a possible criticism of the ingenious empiricism over the concept of the unconscious. Thus, the unconscious, itself, as far as a universal principle and presupposition of any empiricism, can not be empirically conceptualized. But the fact that the consciousness of the other is an inference from the indications that allow the presence of "something" similar to my own consciousness, and that I attribute to my own I, to be discerned is not an object of direct observations, never shook the universal affirmation of the existence of the conscience as psychic reality par excellence. Therefore, if the conscientialist thesis is an inference, which is the foundation and the conditions of possibility of all of scientific production, above all, of the science that is caught up in an empiricist epistemology, then it the empiricist critique of the concept of the unconscious is also neutralized.
We can explain yet another use of the principle of analogy as rhetorical argument. Freud invites the reader to apply the process of inference to him/herself. All of the acts and phenomena that are do not perfectly fit within the flow of consciousness can be considered as belonging to another. According to Freud:

...all acts and manifestations that I observe in myself, and that I do not know how to connect to the rest of my mental life, must be considered as being foreign, belonging to an "other," must be explained by a mental life attributed to this other person (Freud, 1915c, p. 195).

Thus, since I don't have access to the consciousness of the other, and can only infer its existence through indications, I do not have immediate access to the phenomena and acts that are born in my psyche. I can infer, through the indications of the existence of a second consciousness within me, that which appears to indicate the present of an "otherness" within my identity. In this case, Freud would be using an analogy of the second order, an analogy of an analogy. The consciousness of the other is reached by analogy'; creating an analogy with this inference, we can say that the unconscious does not simulate another, only as an exception that this other inhabits my own being. If I apply the principle of the analogy to my own psyche, I can find indications that I do not immediately recognize as my own, which reveals, therefore, another in me, "something" like a "second consciousness."

In Freud's words:

This process of inference, when applied to the individual, despite internal opposition, does not, however, indicate the present of an unconscious; it does indicate, logically, the idea of another, second consciousness that, within the very I of the individual, is united with the consciousness that is known/is self-aware. (Freud, 1915c, p.195)

We perceive yet another function for the principle of analogy: the thesis of universality of the unconscious can be defended through the principle of analogy; the unconscious can also be inferred. If Freud interprets the gaps that occur in his flow of consciousness, and phenomena such as dreams, parapraxis and neurotic symptoms, as indications that attest to the present of an unconscious system within his psyche, through inference, the author can also consider as legitimate the supposition of an unconscious system in other persons that are similar to him. We can consider such phenomena in the other in the same manner that we consider these same phenomena within ourselves, as indications that permit inference of the presence of the unconscious. The statement, "other people possess a consciousness", is a deduction that we infer by analogy. The same rationale can be applied to the unconscious. I can infer, by analogy with my phallic acts, dreams, and symptoms, the existence of the unconscious in other persons. Thus, the principle of analogy enables the universal postulation of an unconscious system.

To apprehend the consciousness of the other by analogy possesses, consequently, the difficulty that accessing my 
consciousness may be apprehended immediately; I can be conscious of my own mental states, but in relation to mental states outside of my own, there is an impassable, empirical barrier. As regard the unconscious, an exception is made necessary: since the unconscious is the principle of otherness within us, it appears that the other has the greater facility in interpreting the indications of the unconscious that blooms within me. The I is directly affected by the content of the unconscious, suffers the consequences of repression, but the other possess an agent with privileged access to scout the phenomena of the unconscious. In this sense, the dimensions of otherness are fundamental in the dynamic of unconscious communication: the analyst has a special place in the process of plumbing the depths of the unconscious, enabling the appearance of an other-transferencial of the subject. The subject projects in the analyst fantasies and desires of their unconscious, thus, despite the analyst being another person, the subject sees the analysis from their own projections.

We observe that the use of the principle of analogy in the metapsychological text, The Unconscious (Freud, 1915c), reveals the presence of the other as a dimension that inhabits the well of the I, and, also, reveals the possibility of apprehending the other by inference. But it would be interesting to apprehend the process of creation of this principle of otherness in me. We would like to reflect on the process of the production of the contents of the unconscious, which inhabits our psyche, but enjoys an ambiguous status, being simultaneously pertinent and foreign to ourselves.

In the text History of the Psychoanalytical Movement (Freud, 1914a), Freud states that the theory of repression is the cornerstone on which the structure of psychoanalysis rests. A fundamental statement of metapsychology, thus, the unconscious, object of psychoanalysis, is the result of the process of repression which brings about the cleavage of the psychic apparatus into two grand systems.

In 1915, Freud reveals that repression, one of the vicissitudes of compulsion, occurs when displeasure invades the psychic apparatus at a time when it should be only that of compulsive satisfaction, transforming the pleasure of satisfaction into displeasure. Displeasure becomes the necessary condition, the motivational force that elicits the process of repression.

Thus, the "movement of removal of the determined item from the consciousness, holding it at a distance"(Freud, $1915 b, p .170)$ is described as being the essence of repression. In the first matter, the content of repression refers to the ideative representatives of conflicting sexual desires. In the process of repression, a separation occurs between the idea and the affect, or rather, between the representativerepresentation and the quanto of affection. The ideative representative will be repressed, expelled from the conscious mind, causing, thus, the cleavage of the psychic apparatus. The affective representative may suffer three different ends: (a) to be repressed or suppressed, meaning, hindered from development; (b) suffer a qualitative transformation, becoming anxiety; or, (c) finally, remain, in whole or in part, just as it is. The affect can not be repressed; the ideal horizon of the process of repression is constituted in the suppression or repression of development of the affect. We can consider quite successful that repression in which the idea is repressed and the affect restrained (suppressed). The result of the affect is fundamental for the success of the repression; since it would be from the free affect that we have the return of the repressed in the form of a symptom. The quantum affect that still spins about the psychic apparatus causes a psychological imbalance. This circulation of the affect requires a formative operation, or rather, the constitution of a form of creative expression that encompasses the interests of the I, as much as the unconscious desires. The symptom, the dream, and the phallic act, are manifestations that make formation of the free energetic quantum possible. The phenomena of the unconscious are fruits of the solution of compromise between the interests of the conscious mind and the anxieties of the unconscious, but the element that demands this creative and strange production (Unheimliche) is the free affect. Phallic acts and their symptoms produce in the I a sensation of "foreignness." It appears that there exists an other within the I, and that it would be responsible for these uncontrollable phenomena. The appearance of uncontrolled demoniac action expresses the strangeness of the I faced with inconsistent phenomena. The unconscious appears to the I as an other within its very being, but it seems important to us to recall that the unconscious is an otherness in its self, but the unconscious symptoms are, as symptoms, phallic acts and creams which make it an otherness for us. The phenomena of the unconscious represent, in a dislocated and condensed manner, the repressed contents, or, that is, are symbolic forms, distorted by censorship, of the ideative, compulsive representatives that are repressed. But we insist in the fact that the free affect is what would be the efficient cause, the energetic cause, for production of the symptoms and other phenomena that we attribute to the unconscious. In this sense, we wish to defend the thesis that it is the existence of the free affect, disconnected from the representations, that brings about the experience of otherness which lives deep within the hidden recesses of the I.

The theory of representation has an extended tradition in modern thought. Thus, the conceptual or ideative representation would constitute the starting point for all philosophical or scientific theorization on knowledge. The representation makes possible theoretic production, mediation, and contact with reality, itself. All experience and all contact with reality is translated into concepts, or rather, is represented abstractly. And, if knowledge aims at the identity between being and reason, then to know would signify, in a way, the reduction of the other to the same.

The philosophical project initiated by Plato sought to construct a science of the truth, of the stable, however, from 
the perspective of platonic philosophy, being is the same as reason. It is this equivalent that is questioned by Levinas when the author proposes the primacy of ethics over ontology. The other possesses an irreducible dimension that survives even when rationality tends to reduce the other to the same. And we can not forget that modern analysis of the platonic ideal, which is found, for example, in Husserl, requires an intentional I to control and contain the excess of immediate experience through representations.

Nevertheless, the representation only retains coagulated and superficial elements of the experience in itself. Something always escapes language; reason does not succeed in encapsulating the fullness of reality. Abstract or rational knowledge makes possible symbolization, fixation and universalization of experience, and, no less important, it allows communication, the symbolic exchange of experience. Thus, without the world of representations, men would be condemned to isolation, since it is the power of representing things that is the condition that enables opening of the man to the world. But the price of this possibility of symbolic exchange is the fixation of the establishment of experience. The world as representation, as product of intelligible and intentional knowledge, reduces the entirety of the otherness of experience to the same as that of language. Emotion does not follow the representation of the object, it precedes it. Man is affected by the world, the whole hodgepodge of sensations is translated and organized in words. The representational organization of experience provides man a certain control over his experiences. The human subject is exposed without defense to all kinds of experience. Intelligible knowledge affords a kind of defense against this exposure in all its force and nakedness. Nonetheless, that which first was a defense ends up becoming a symptom: Man hides himself from reality behind the representation, and the distance between experience and concepts appears to grow ever larger, bringing man to fail to acknowledge his own experiences in all of their density and richness, and acknowledge only those mediated, selected and controlled by the concept. In this sense, it is that which justifies the feeling of foreignness that is experienced before affection, like a free "real" of the ideative representation. In the process of repression, the separation between affect and idea brings about a world where conceptual mediation is barely elaborated. Free affection, without the mediation of the conceptual representation, produces in man the sensation of something sinister. Emotion precedes the intelligible representation of the conscious mind, which reduces the other to the same, the free affection is pure otherness. It is not perfectly adapted to the typical logic of conscious production of intelligible and controlled concepts. Thus, it appears to us that the sensation of foreignness produced by the symptom is a product of the separation between affection and idea, since this sensation can be reinforced when the affect is tied to another idea that maintains a distant relation to the original idea. The logic that dominates the principle of the link between free affection and a new idea, unlike the principle of identity, follows metonomical and metaphorical logic. There is not, however, within the unconscious principle of identity, in it, being is not equal to reason. Thus, for the conscious I, faithful to the logic proposed by modern rationality, psychological symptoms appear as strange monsters, figures beyond the field of control, literally a "non-I".

\section{The Superego as Other and the I as Object}

Freud begins his Conference XXXI, "The Dissection of Psychological Personality," departing from ruminations on ego and indicating that his exposition on the psychology of the ego should introduce a new understanding of the psychological underworld (Freud, 1933/1932, p. 64). In the study on ego, an epistemological impasse is re-instated: how to place our own I as the object of research? In Freud's words: "The ego is, in it's very essence, subject; how can it be made an object?" This is a classical objection broadly consecrated in treatment of the history of psychology. Comte, for example, criticized the constitution of a new science, objecting that: "The mind can observe all phenomena, except its own. The observer and the observed are identical" 8 . Freud would neutralize this objection, and, thus, refute the scientific confidence in conscientialism and in the unit of the mind. Ego can be divided, and, thus, be taken to itself as object, can observe and criticize itself (Freud, 1933/1932, p. 64). In the pathological process of insanity, the egoist division is sufficiently evident. However, the division of the ego is not exclusive to psychosis, since clinical evidence provide Freud with the perception of the existence of an observing instance that keeps the ego under surveillance and exercises its activity of judging and castigating the ego itself. This instance was significantly called "the superego". The superego incarnates and expresses the presence of a moral "otherly-other" within the I. The superego appears to be the moral duplicate of the I, the other of the same I, that vigil that observes and morally regulates. The concept of the superego as an otherness would find explanation in the Freudian statement that the superego assumes the roll performed, in the beginning, by an external power, by the parents' authority (Freud, 1933/1932, p. 67). In this sense, the superego would necessarily be an otherly instance, since

8 Cited by Schultz, D.P., \& Schultz, S.E. (1992). História da psicologia moderna (History of Modern Psychology) São Paulo: Cultrix. 
it is representative, not only of the "paternal other", but of the parents' superego, or, rather, the "Other", of culture itself. As the Superego is the representative of the moral, it is fitting that we reflect on its historical determinations, since the superego of the child is constructed according to the model of the child's parent, and these, in turn, are inspired in their parents, and so forth, "retroprogressively". The superego, according to Freud, becomes "the vehicle of tradition and of all the long-lived value judgements that in this way are transmitted from generation to generation. [...] The past, tradition of race and of the people, live in the ideologies of the superego..." (Freud, 1933/1932, p. 72).

The principle of otherness, which thrives in the core of the superego, is placed, therefore, as a result of the process of formation of this instance, and, thus, the form as the superego acting in the psychological make-up will reproduce the otherly perspective. Actions originating in the superegoist force produce in the I a sensation of strangeness, something that the I does not recognize as its own. Thinking, primarily, in the formation of the superego, we can state that it is not a coincidence that in the first page of the chapter dedicated to presenting the superego, Freud (1923) begins with a reflection on melancholy and identification, or, more precisely, melancholic identification. The process of identification and melancholy operate by the principle of otherness.

Identification is defined by Freud as, "the action of making one ego similar to another ego, in consequence of which, the first ego behaves like the second in determined aspects, imitates it, and, in a certain sense, assimilates it within itself" (Freud, 1933/1932, p. 68).

In this way, a change occurs in the ego in the process of identification, resulting from its approximation to another. However, Freud describes, at the very least, three types of identification: the first would be the result of a primitive process, incorporation; the second arises from regression of an objectal choice; the third would not be the consequence of an explicit objectal cathexis. All three of these types of identification may be implicated in the process of the formation of the superego. Regardless of the method of identification, the common thread of the various types of the relation to the dimension of otherness. The process of identification requires the presence of an other and the assimilation on the part of the I of the elements of this other. This, the meeting of the familiar other (parents) is primordial under the conditions of the possibility of the constitution of the superego. According to Freud, the superego is the result of the formation of a precipitate in the ego, consisting of these two (maternal and paternal) identifications united with each other in some manner (Freud, 1923, p. 49). The superego is formed from the remains of the Oedipal love, the love of the I attempts to negate as itself, refute the legitimacy of this love, which, in truth, has its origin in the Id.

The moral instance is the final product of a process that involves cathexis and identifications within the Oedipal experience. The others-objects of the libidinal investment in the Oedipal complex are the parents, or rather, those which exercise the function of mother and father. This first object of love must be abandoned, allowing opening of the subject to other objects. The abandonment of this object is followed by the alteration of the ego, which, using the model of melancholy, refers to the installation of the object within the ego. According to Freud, "it may be that this identification is the only condition in which the id may abandon its objects" (Freud, 1923, p. 43). On the other hand, identification assimilated as a thread of the ego, which reproduces a characteristic of the abandoned object, functions as a possibility of control of the ego over the id. The superego would be, thus, the most important identification of this type. The objectal libido, abandoned in the Oedipal scene, must be transformed to a narcissistic libido, or, rather, the impediment of the free drainage of the cathexis toward the object makes the libido turn inward. This process, which we summarily describe, implies a renunciation of sexual objectives, which could be interpreted as a conceptualization, and this would be the foundation of the very process of sublimation. In a certain manner, the superego is a form of sublimation and a type of melancholic introjection.

In the melancholic vision, the I is lost, does not recognize itself, feels like a stranger to itself. The idea of a narcissistic identification in melancholy is perfect, since it propels us towards the myth of Narcissus who was already dead within himself before plunging into the water. Narcissus did not live the experience of otherness, except in the experience of being a pair within himself, or an other that had as object his very self. Narcissus is the prisoner of the alienating sameness of his own image, but the captivity in sameness does not even point to a comprehension of himself, nor is it a strong experience of identity. Narcissus lives the fractured existence of being other, a reflective other that is the omen of death, since in him there is no separation of the "same". In melancholy, the subject is invalidated by the other, crossed by pain, and is lost, without the possibility of transforming this pain into a true experience of meeting with the Otherness, internal and external. The other exists in melancholy, however, this other is reflective, or rather, is situated in the dimension of sameness. According to Vasse:

The secret of man is the desire of the Other. But, if to remain imprisoned in the web of a structure that can, imaginarily, reduce it to the Same, man loses his secret, and, in an ever more mortifying conformity, his images, his own name and, even his identity passes to be strange to him, since the suffering means nothing beyond his alteration (Vasse, 1983, p. 33).

Thus, by principle, the process of melancholy is based on a meeting with the other. However, this meeting possesses low density otherness; since it is an other, but the melancholic assimilation disavows the other in its difference. In the process of melancholic introjection, the other is assimilated as a "same". 
In this manner, the superego is constructed from a meeting with otherness, since, at the base of its process of formation we have the identification and melancholy. But, we must emphasize that, melancholy being the paradigmatic model of the formation of the superego, it may present pathological content and action which escapes the comprehension of the I. Thus, if, on one hand the superego is internal representative of the moral, the other, this agent may express its moral perspective in the same pathological manner. Regardless of its position, the action of the superego is perceived by the conscious I as a foreign invasion. In truth, the I representative of the modern dream of autonomy more easily perceives the pathological actions of the superego as foreign invasion, as is the case in moral masochism. Because, the psychopathological masochist requires the presence of the other as sadistic agent, but, in the case of moral masochism, which is characterized by Obsessive Neurosis, this agent is found within the I. The otherly-other in the image of the superego prevails over the I, being able to exercise its sadistic dominion on the I.

We know that masochism appears as one of the selfdestructive forms of relation between the I and the other. There is no negation or neutralization of the otherness in the economy of masochism. The other is untouchable, since it is through its presence that meeting with suffering is accomplished. We find in Freud's work various references to the problem of masochism, references which run through the development of his work and the construction of his metapsychology. Since the first allusions [the first refers to masochism, a fiancée arranged flowers in the center of a table through the idea of a feminine masochistic character of deflowering] until its link with sadism and its integration, through the Three Essays (Freud, 1905), in a general theory of sexuality from 1914 to 1923 , Freud maintains the idea of an original sadism, but developed, in relation to masochism, the fundamental ideas of feelings of guilt and fear of castration, as well as the idea of the phantasm as support of desire. After 1920, the concept of the compulsion of death brought him to rethink his position on masochism, which came to be conceived as original, which shed new light on the clinical approach to Melancholy and Obsessive Neurosis, through the link between masochism and feelings of unconscious guilt. In 1924, Freud wrote the text The Economic Problem of Masochism, which established, definitively, the result of his reflections.

Freud presents three types of masochism, differentiated in a phenomenological sense. Feminine masochism, which is based entirely on erogenous masochism, reveals fantasies, frequently present in men, such as to be spanked, to be copulated, to be castrated or blinded. Such fantasies appear to be linked to the search for discipline intended for the incestuous Oedipal desires, such as the fantasy of being blinded, which is associated, since Sophocles tragedy, with Oedipus' destiny. In moral masochism, which refers to the assumption of Oedipal guilt, the sadistic agent that attacks the ego is internal; It is the super-ego. In the case of production of the superego, we know that a diffusion occurs, resulting from sublimation. The libidinal energy invested in the Oedipal relation returns so that the I suffers desexualization, thus causing the final sublimation of the superego, the otherly-other that assumes the role of censor to the ego. Thus, moral masochism is presented as a psychopathological exit, where the otherly-other is the sadistic agent. Freud reveals:

The conscience is the morality that arrises via superation, the complete desexualization of the Oedpius; through moral masochism, however, morality once again becomes sexualized, the Oedipal complex is relived and a way is opened for the return of morality for the Oedipal complex. (Freud, 1924, p. 211).

Thus, moral masochism represents a form of selfpunishment for the Oedipal desire. An excerpt from of a case in my own practice can, perhaps, illustrate how this process of super-egoist self-punishment relates to Oedipal desires. Francisco is 25 years old, and is the youngest child of a family that has 4 sons. His father is 88 and his mother is 55 years old. The father is authoritarian and beat his sons until they reached the age of 18 years, and managed all of the family's money, himself. The mother's inheritance is under the father's control, and, hence, the lands, also in his power, are abandoned. Francisco completed studies in Agronomy, returned to the birth city of his mother, married, and resolved to invest in his parent's farm. The father charged rent for the use of the lands. Francisco has advanced technical knowledge in the area of swine production. He did significant internships, received various invitations to work for large businesses, but left everything behind to return to his mother's soil. He took several loans at a bank, using the family name of his maternal grandfather. All of the money was invested in the farm, he sought to produce more than had ever been produced on his maternal grandfather's lands, because, for this grandfather, work on the land has no value, one must only accumulate estates, and the lands, even if unproductive, are a sign of wealth and power. Francisco worked hard, from sunrise to sunset, but when harvest time arrived, he was not able to harvest; he became possessed by a debilitating guilt, but did not know why. All his product was lost, and Francisco was unable to pay his loans. From there, this unconsciously sought weakness produced an unpayable debt with the bank, concretizing, in the materiality of money, his symbolic debt. The omnipotent desire to execute a task prohibited by family history, an impossible task, arising from incestuous desire to fertilize his mother's lands, drove him to impotence and to an existential impasse. The super-egoist guilt produced the weakness and paralysis.

In the field of superegoist pathology, it is easy to visualize the intervention of an other foreign to the I, but, how does one support the foreignness of a superego that slide towards pathology? The argument that supports the foreignness for the I of a superego representative of morality 
must be sought within Freudian theory. The anthropological concept commensurate to Freudian theory describes man as an aggressive being. We can cite the famous passage of the text Malaise in Civilization:

Men are not gentle creatures that want to be loved and that, at best, can defend themselves when attacked; on the contrary, they are creatures among whose instinctive inheritances must taken into account a powerful capacity for aggression (Freud, 1930/1929, p. 133)

In this way, an instance constitutive of the subject that aims to contain this structural aggression may appear a force imposed by an other. In Reflections in Times of War and Death (Freud, 1915d), Freud made it clear that moral behavior is an external imposition for the I through susceptibility to culture (p. 319). Pressure from the immediate cultural environment, and also historical cultural influence from ancestors, transforms egoism and cruelty, under the influence of eroticism, the necessity for love, in moral conduct. Thus, this susceptibility may be temporarily reversed by the situation of war (p. 323).

When the community doesn't raise further objections, an end to suppression of passions is also verified, and men perpetrate cruel and barbarous acts, fraud, and treason so incompatible with their level of civilization, that anyone would judge them impossible. (Freud, 1915d, p. 324 )

Thus, for the conscious I, sovereign and autonomous, the superego is produced from foreign dimensions, and, in turn, the actions of this instance are not recognized as belonging to the identity of the I. To analyze the superego from it's constitution allows us to confirm its conditions of foreign in the topic, since the superego permis control of the Id by the ego, but, paradoxically, is not allied with the ego, but is sometimes a foreign torturer of the I. On the other hand, the super ego may be described as unconscious, without belonging to the unconscious system, therefore, a true "alien".

\section{The Id as Other: Radical Foreignness}

As the second topic and introduction of the concept of the Id, we may consider that there arises in the Freudian work an even more radical image of the otherly-other. The introduction of this new psychic instance does not imply abandon of the idea of the unconscious system, but also, it is not only a new name for the same. The Id, similar to the Unconscious system, does not obey the laws of logic, since the absence of the principle of contradiction and of the principle of negation would be clinically confirmed through observation of the formations of the unconscious. In the same way, also for the Id, the forms of space and time are not a possible condition for their psychic processes. Being situated outside of time and the laws of logic, the Id also disavows value judgements, and, consequently, fails to recognize the difference between good and evil.
The clinic of psychosis interrogates the first Freudian topic and reveals its limits. Discussion of the libido of the I or narcissus is a paradigmatic example of this questioning. We know that there is no repression in psychosis and that no delirium suddenly return to something in the order of compulsion and the unconscious. The unconscious content of delirium is not reduced, evidently, to the concept of the descriptive unconscious, since in delirium we are not dealing with the contents of easy conscious access. The fragile structure of the psychotic is divided, fragmented between different Is. But also, because there is no repression, we cannot confirm that it is simply a phenomenon of the unconscious, in the sense of the first topic, because, there is no repression. It is necessary, then, to elaborate a third sense for the word "unconscious", in order to enable a better comprehension of psychosis. In psychosis, compulsion appears to juxtapose the symbolic, which intends to insert the subject in the record of representations. What is in list, in this point, is the criticism and limits of representation. The unconscious system, as conceived in the first topic, is the result of repression of the ideative representations, thus the affect is separated from the idea and possesses a different purposes from it. Thus, repression refers to the contents that are written in the field of representation, psychosis appears to announce another type of unconscious material.

Freud is seen, thus, compelled to seek a new purposes for the term "unconscious". By suggestion from Groddeck, he adopts a term originally from the Nietzchean "Das Es", translated in its Latin form as "Id." This Latin word represents a demonstrative pronoun; It doesn't present a content or form. It is only "this." It is precisely for this "foreignness" that it was not possible to define the Id, attributing to it a clear conceptual determination, since the Id is that which resists any determination and can only be understood negatively, by contrast with the Ego, or through analogy. In the words of the master:

We approach the id with analogies; We call it 'chaos', a cauldron boiling over with agitation. We describe it as being open, in its extreme, to somatic influences and as containing within itself compulsive needs that find within it psychic expression... (Freud, 1933/1932, p. 78).

The Id is an anarchic field replete with energy that, lacking intentionality, can not consider the outer world; It is closed within itself; It is full of virtually immoral desires. According to Freud, "it does not express collective will, but only a struggle for the attainment of satisfaction of compulsive needs, subject to observance of the pleasure principle"(Freud, 1933/1932, p. 78).

Thus, it incarnates the very principle of otherness, being always foreign and not allowing itself be captured, casts its sinister shadow over the I in the form of a dominating other. In LaPlanche's interpretation, the Id became unconscious but foreign and closer to the vital forces. (Laplanche, 1978, p. 157). The foreignness of the Id is guaranteed by the introduction of three incomplete dimensions in the definition 
of the unconscious in the first topic. In the first place, through the idea of the Id, psychoanalysis may consider the compulsive perspective more appropriately, over all the dimension of compulsion that escapes representation. In second place, the Id opens a reflective space for discussion of phylogenetic inheritance, over that which, in the individual, radically goes beyond it. And, finally, the neutral pronoun "Es" enables acknowledgement of the impersonal nature as structuring agent of the subject, a concept that brings us back to the tradition of romanticism and indicates a certain juxtaposition in relation to philosophy of light and the subject (Laplanche, 1978, p. 156).

Therefore, the introduction of the idea of the Id would express a movement toward the interior of the psychoanalytical theory, a new direction in relation to the problem of anxiety, considered as a primordial affect. Anxiety would not be only the remains of repression, but would be, overall, the zero degree of the process of subjectification. We cannot doubt that Freud has been doing a reformulation in his theory of anxiety, since he, himself, says explicitly: "The conception of anxiety, I was defending in this essay, has moved a bit from that which seemed justified until then" (Freud, 1926, p. 185). And, continues confirming that this reformulation must be considered as a consequence of the new division of the psychic apparatus (Id, ego, and superego; Freud, 1926, p. 185). In the first topic, anxiety appears as the result of repression; In the second topic, Freud favors the anxiety of castration that represents the original anxiety (Urangst) or the real-anxiety (Realangst). This new theory of anxiety opens the discussion for the limits of representation, since original anxiety can not be completely captured by the world of representation. This field of non-representable anxiety is connected to the concept of moral compulsion. As Rocha reveals, the compulsion of death obligated Freud to also review his conception of the Unconscious, which, until then, was primarily constituted by representations or contents representative of repression (Rocha, 2000, p. 100). Thus, the topical-dynamic vision in the first topic was giving preference to an economical approach, in which the Id came to be considered an original source of the libido (Rocha, 2000 , p. 100). Thus, the Id comes to be the seat of unnameable affects that evade representation. According to LaPlanche:

...of affects that appear to arise from the depths of the Id, a simple and banal observation imposes itself: such an affect, in the very measure in which it is independent from its representative cortex, independent of a fantasy, is directly marked by anxiety (Laplanche, 1978, p. 161).

For Andre Green, the primordial difference between the unconscious system of the first topic and the Id is not the fact that, in the last, there is room for the compulsion of death (Green, 1973, p. 215), or rather, through it, that which is imposed is the acknowledgement that in the foundation of the subject there lives something beyond representation, a "something" like a hole, a nothing, which is, however, effective when it is manifest as anxiety. Thus, the Id is the stage for affects that escape representation, for unthinkable anxieties that frustrate the Id and are perceived as a radical otherness. The innovation of the concept of the compulsion of death is that of offering a place in the psychoanalytical scene for the affects that are not representable, but that ravage the I, even though this does not succeed in decoding them. The sovereign I, conscious and autonomous, perceives as foreign that which does not conform to the field of representation. We return to the image of abandon present in the production of the symptoms, but now with more radicality.

It seems that the Id is the most obscure form of the image of the otherly-other, that which inhabits the "foundation" of the subject and would be found "beyond" or "beneath" the forms consecrated by the Modern Science of representation. The Id presents a dimension of an original otherness. That which is the most foreign, which escapes the logic of representation and that reveals: "the I is, and alway was, an other".

\section{Some Partial Conclusions}

The first Freudian concept that makes this image of otherness effective is the unconscious system. The dimension of otherness of the unconscious is primarily perceived from the analogical construction between the inference of the conscious of the other and the inference of another consciousness within the I. Through this analogy, Freud defends the thesis of the existence of the unconscious and its universality. The unconscious, according to this logic, would be the other, and, thus, appears to us relevant to the idea that in order to access the unconscious, the presence of the other is important.

But the dimension of otherness of the unconscious goes beyond the theoretical dominion of the analogy and is translated in the tangibility of the psychic processes, or, rather, the dynamic of the production of this system, visible clinically, and which produces its condition of otherness. The separation between the affective and ideative representatives, condition for repression, produces a feeling of foreignness before the free affect, dislocating ideative representation.

On the other hand, the unconscious is the result of the meeting between the various images of otherness. Repression is produced from the prohibition of the Law (radical otherness) over the little Oedipus, as far as its incestuous other-object. The forbidden desire, prohibited, castrated, is the condition of possibility of the repressed unconscious, which we here refer to as the "otherly-other". What is interesting here is that this logic of the production of the unconscious has another byproduct, which also represents a figure of otherly-other, namely, the superego. 
Finally, we have the Id as an image of the otherly-other, constructed in the field of pure otherness, escaping, thus, greater theoretical determination. We believe that we can conceive a gradation between these three figures of the otherly-other, according to the logic of a greater reflective density. The Id represents a more "abstract" image in the field of otherly-other, and, in this sense, is the most difficult concept to understand. Next, we have the superego, which, despite being presented as a breakdown of the I, is connected before the compulsive field, and, finally, we have the systematic unconscious, which, constituted from the other, is presented to the conscious in various clinical phenomena.

Thus, the I perceives the unconscious system, the superego, and the id as foreign strangers, not recognizing these otherly figures as belonging to the subject. According to Freud (1917), the discovery of the sexual compulsion and of the unconscious are equivalent, however, to the statement that "the ego is not the master of his own house." Thus, it is no wonder that "the ego does not look favorably on psychoanalysis and obstinately refuses to believe in it" (Freud, 1917, p. 178). In conclusion, we would like to present a Freudian prescription:

You behave as an absolute dictator, that is content with the information provided by its closest advisors, and never mixes with the common people to here their voice. Turn your eyes inward, contemplate your own depths, learn first to know yourself! Then, you will understand why you become ill, and, perhaps avoid illness in the future. It is thus that psychoanalysis has sought to educate the ego (Freud, 1917, p.178).

\section{References}

Assoun, P.L. (1978). Freud, filosofia e filósofos. Rio de Janeiro: Francisco Alves.

Fernandes, L. R. (2000).O olhar do engano - autismo e outro primordial. São Paulo: Escuta.

Freud, S. (1914a). The history of the Psychoanalytic. The Standard Edition of the Complete Works of Sigmund Freud, 24 volumes, ed. by James Strachey et al. The Hogart Press and the Institute of Psychoanalysis, London 1953-74, 14. [FREUD, S. [1914] História do movimento psicanalítico. Edição Standard Brasileiras da obras completas de Sigmund Freud. (E. S. B.). Vol. XIV, Rio de Janeiro, Imago, 1974, pp.13-84.]

Freud, S. (1915a). Instincts and their Vicissitudes.The Standard Edition of the Complete Works of Sigmund Freud, 24 volumes, ed. by James Strachey et al. The Hogart Press and the Institute of Psychoanalysis, London 1953-74, 14. [FREUD, S. [1914] Os instintos e suas vicissitudes. Edição Standard Brasileiras da obras completas de Sigmund Freud. (E. S. B.). Vol. XIV, Rio de Janeiro, Imago, 1974, pp.129-164.]

Freud, S. (1915b). Repression. The Standard Edition of the Complete Works of Sigmund Freud, 24 volumes, ed. by James Strachey et al. The Hogart Press and the Institute of Psychoanalysis, London 1953-74, 14. [FREUD, S. [1914]
Repressão. Edição Standard Brasileiras da obras completas de Sigmund Freud. (E. S. B.). Vol. XIV, Rio de Janeiro, Imago, 1974, pp.165-184.]

Freud, S. (1915c). The Unconscious. The Standard Edition of the Complete Works of Sigmund Freud, 24 volumes, ed. by James Strachey et al. The Hogart Press and the Institute of Psychoanalysis, London 1953-74, 14. [FREUD, S. [1914] O Inconsciente. Edição Standard Brasileiras da obras completas de Sigmund Freud. (E. S. B.). Vol. XIV, Rio de Janeiro, Imago, 1974, pp.185-248].

Freud, S. (1915d). Reflections on War and Death. The Standard Edition of the Complete Works of Sigmund Freud, 24 volumes, ed. by James Strachey et al. The Hogart Press and the Institute of Psychoanalysis, London 1953-74, 14. [FREUD, S. [1914] Reflexões para os tempos de guerra e morte. Edição Standard Brasileiras da obras completas de Sigmund Freud. (E. S. B.). Vol. XIV, Rio de Janeiro, Imago, 1974, pp.310-344].

Freud, S. (1917).. One of the Difficulties of Psycho_analysis.The Standard Edition of the Complete Works of Sigmund Freud, 24 volumes, ed. by James Strachey et al. The Hogart Press and the Institute of Psychoanalysis, London 1953-74, 17. [FREUD, S. [1917] Uma dificuldade no caminho da psicanálise. Edição Standard Brasileiras da obras completas de Sigmund Freud. (E. S. B.). Vol. XVII, Rio de Janeiro, Imago, 1974, pp.169-182.]

Freud, S. (1923 a). The Ego and the Id.. The Standard Edition of the Complete Works of Sigmund Freud, 24 volumes, ed. by James Strachey et al. The Hogart Press and the Institute of Psychoanalysis, London 1953-74, 19. [FREUD, S. [1923] $O$ ego e o Id. Edição Standard Brasileiras da obras completas de Sigmund Freud. (E. S. B.). Vol. XIX, Rio de Janeiro, Imago, 1974, pp.13-86.]

Freud, S. (1924). The Economic Problem in Masochism.The Standard Edition of the Complete Works of Sigmund Freud, 24 volumes, ed. by James Strachey et al. The Hogart Press and the Institute of Psychoanalysis, London 1953-74, 19. [FREUD, S. [1924] O problema econômico do masoquismo. Edição Standard Brasileiras da obras completas de Sigmund Freud. (E. S. B.). Vol. XIX, Rio de Janeiro, Imago, 1974, pp.196-214]

Freud, S. (1926/1925). Inhibition, Symptom and Anxiety.The Standard Edition of the Complete Works of Sigmund Freud, 24 volumes, ed. by James Strachey et al. The Hogart Press and the Institute of Psychoanalysis, London 1953-74, 20. [FREUD, S. [1926/1925] Inibição, sintoma e ansiedade. Edição Standard Brasileiras da obras completas de Sigmund Freud. (E. S. B.). Vol. XX, Rio de Janeiro, Imago, 1974, pp.95204]

Freud, S. (1930/1929). Civilization and its Discontents.The Standard Edition of the Complete Works of Sigmund Freud, 24 volumes, ed. by James Strachey et al. The Hogart Press and the Institute of Psychoanalysis, London 1953-74, 21. [FREUD, S. [1930/1929] O Mal-estar na Cultura. Edição Standard Brasileiras da obras completas de Sigmund Freud. (E. S. B.). Vol. XXI, Rio de Janeiro, Imago, 1974, pp.75-174] 
Freud, S. (1933/1932). New Introductory Lectures on PsychoAnalysis.The Standard Edition of the Complete Works of Sigmund Freud, 24 volumes, ed. by James Strachey et al. The Hogart Press and the Institute of Psychoanalysis, London 195374, 22. [FREUD, S. [1930/1929] Novas Conferências introdutórias sobre psicanálise - A dissecção da personalidade psíquica. Conference XXXI. Edição Standard Brasileiras da obras completas de Sigmund Freud. (E. S. B.). Vol. XXII, Rio de Janeiro, Imago, 1974, pp.63-84]

Garcia-Roza, L. A . (1987). Freud e o inconsciente ( $3^{\text {rd }}$ ed.). Rio de Janeiro: Jorge Zahar.

Green, A . (1973). The fabric of affect in the psychoanalytic discourse. London: Routledge, 1999 [ O discurso vivo - uma teoria psicanalítica do afeto Rio de Janeiro: Francisco Alves, 1982.]

Kant, I. (1785). Groundwork of the metaphysics of morals. Radford: Wilder Publications, 2008 [ Fundamentação da Metafísica dos costumes. Coleção Pensadores. São Paulo: Abril Cultural, 1980.]

Lacan, J. (1966). Écrits: the first Complete Edition in English. New York: W.W. Norton and Co., 2007. [Ciência e a verdade. In Escritos. Rio de Janeiro: Jorge Zahar, 1998.]

Laplanche, J. \& Pontalis. J.b. (1967). The language of Psychoanalysis. New York: W.W. Norton and Co., 1974 [Vocabulário de Psicanálise. Rio de Janeiro: Imago, 1970.]

Laplanche, J. (1978). The unconscious and the Id: a volume from Laplanche's Problematiques. London: Karnac Books, 1999. [O inconsciente e o id - problemática IV. São Paulo: Martins Fontes, 1992.]
Lévinas, E. (1983). A consciência não-intencional In. Entre nós ensaios sobre a alteridade. Petrópolis: Vozes, 1997.

Lévinas, E. (1989). Do uno ao outro. In Entre nós - ensaios sobre a alteridade. Petrópolis: Vozes, 1997.

Milner, J-C. (1996). The clear work Lacan, Science, Philosophy [Obra Clara. Lacan, a Ciência, a Filosofia. Rio de Janeiro, Jorge Zahar.]

Rocha, Z. (2000).Os destinos da angústia na psicanálise freudiana. São Paulo: Escuta.

Schopenhauer, A. (1819). The world as Will and representation. Peter Smith Publisher Inc., 1969 [ O mundo como vontade e representação. Porto/Portugal: Rés].

Severino, E. (1984). La filosofia moderna. Milano, Rizzoli. [ A filosofia moderna. Lisboa, Edições 70.]

Severino, E. (1986). A filosofia contemporânea. Lisboa: Edições 70.

Schultz, D.P., \& Schultz, S.E. (1992). History of modern psychology [Translation: História da psicologia moderna São Paulo: Cultrix.]

Verneaux, R. (1963). Histoire de la philosophie moderne. Paris: Beauchesne.

Vasse, D. (1999). O peso do real - o sofrimento. Rio de Janeiro: Revinter.

Received January 8, 2007

Revision received July 24, 2007

Acepted December 26, 2007 
